\title{
Age-dependent changes in anti-Müllerian hormone levels in Lebanese females: correlation with basal FSH and LH levels and LH/FSH ratio: a cross-sectional study
}

\author{
Eddie Racoubian ${ }^{1}$, Gulzhanat Aimagambetova², Ramzi R. Finan ${ }^{3}$ and Wassim Y. Almawi ${ }^{2,4,5^{*}}$ (i)
}

\begin{abstract}
Background: To investigate the age-dependent changes in circulating anti-Müllerian hormone (AMH) levels in healthy Arabic-speaking Lebanese women, and to correlate changes in serum AMH levels with serum FSH and LH values, and LH/FSH ratio.

Methods: Cross-sectional study, involving 1190 healthy females, age 17-54 years, with regular menses and both ovaries. Serum AMH levels ( $\mathrm{ng} / \mathrm{ml}$ ) were measured by ELISA.

Results: There was an inverse proportion of AMH and subject's age, which declined from median $6.71(2.91) \mathrm{ng} / \mathrm{ml}$ in young subjects, to $0.68(0.45) \mathrm{ng} / \mathrm{ml}$ in subjects older than 50 years. Average yearly decrease in median AMH levels was $0.27 \mathrm{ng} / \mathrm{ml} /$ year through age 35 , but then diminished to $0.12 \mathrm{ng} / \mathrm{ml} /$ year afterwards. Receiver operating characteristic curve analysis demonstrated high sensitivity and specificity of age as determinant of AMH levels. In contrast to AMH, FSH levels increased progressively from $5.89(0.11-62.10) \mathrm{ng} / \mathrm{ml}$ in young subjects, to $38.43(3.99-88.30) \mathrm{ng} / \mathrm{ml}$ in subjects older than 50 years. On the other hand, age-dependent changes in LH/FSH ratio paralleled those of $\mathrm{AMH}$. Linear regression modeling testing the independent effect of $\mathrm{AMH}$ on $\mathrm{FSH}$ and $\mathrm{LH}$, adjusted for age, showed that $\mathrm{AMH}$ was significant predictor of FSH and LH/FSH ratio, but not LH. This did not contribute significantly to baseline LH and FSH prediction.
\end{abstract}

Conclusions: Circulating AMH levels are inversely related to age as also shown elsewhere, and are predictors of LH/FSH ratio and FSH but not LH levels in eumenorrheic females.

Keywords: Anti-Müllerian hormone, Follicle-stimulating hormone, Luteinizing hormone, Menopause

\section{Background}

Anti-Müllerian hormone (AMH) is $140 \mathrm{kDa}$ disulfidelinked homodimeric glycoprotein, belonging to transforming growth factor- $\beta$ (TGF- $\beta$ ) superfamily [1], is essential factor involved in the regression of Müllerian ducts in the male fetus (reviewed in Josso [2]). AMH is produced in high amounts by Sertoli cells in males from

\footnotetext{
* Correspondence: wassim.almawi@outlook.com

${ }^{2}$ School of Medicine, Nazarbayev University, Nur-Sultan, Astana, Kazakhstan ${ }^{4}$ Faculte' des Sciences de Tunis, Universite' de Tunis El Manar, Tunis, Tunisia Full list of author information is available at the end of the article
}

testicular differentiation up to puberty, and in lower amounts by granulosa cells of primary and small antral follicles in females from the second half of intrauterine life up to menopause $[3,4]$. The main role of AMH is regulation of fetal male sex differentiation, while other roles in ovarian follicular differentiation and elsewhere have been described (reviewed in Josso [2]).

AMH is activated by proteolytic cleavage of proprotein, and binds specific AMH type 2 receptor [4], followed by the recruitment of SMAD signal transducer proteins [5], leading to their nuclear translocation where

C C The Author(s). 2020 Open Access This article is licensed under a Creative Commons Attribution 4.0 International License, which permits use, sharing, adaptation, distribution and reproduction in any medium or format, as long as you give appropriate credit to the original author(s) and the source, provide a link to the Creative Commons licence, and indicate if changes were made. The images or other third party material in this article are included in the article's Creative Commons licence, unless indicated otherwise in a credit line to the material. If material is not included in the article's Creative Commons licence and your intended use is not permitted by statutory regulation or exceeds the permitted use, you will need to obtain permission directly from the copyright holder. To view a copy of this licence, visit http://creativecommons.org/licenses/by/4.0/ The Creative Commons Public Domain Dedication waiver (http://creativecommons.org/publicdomain/zero/1.0/) applies to the data made available in this article, unless otherwise stated in a credit line to the data. 
they regulate target gene expression $[1,4,5]$. Along with its role as determinant of the male sexual differentiation, changes in AMH levels, together with follicle-stimulating hormone (FSH) and luteinizing hormone (LH), reflect aging in females [6]. This age-dependent decline in fertility typically begins at the third decade of female's life and deteriorates markedly after age 35 years old. This decline is attributed to gradual age-related decrease in the pool of ovarian follicles [7], coupled with increases in follicularphase serum FSH and LH levels [8].

While LH and FSH levels are determinants of ovarian activity, AMH levels reflect ovarian reserve. AMH serum levels are reliable indicators of ovarian reserve (follicular pool) in reproductive age women [3, 9], as they remain constant throughout the menstrual cycle [10, 11], with low variability in subsequent cycles [2], and are not affected by endocrine perturbations [5, 10, 11]. Clinical studies demonstrated that decreased AMH levels indicates reduced ovarian responsiveness to exogenous gonadotropin administration, and poor pregnancy outcome in women undergoing infertility treatment [9]. Serum AMH levels correlate with follicle count $[12,13]$, and are more accurate than age and other conventional markers (FSH, estradiol, inhibin B) in predicting pre-ovulatory oocyte supply in response to ovulation induction [14]. Clinically, AMH determination is utilized in assessing ovarian reserve in infertility diagnosis, premature ovarian failure, and polycystic ovary syndrome (PCOS) $[2,15]$. A recently published systematic review reported that $\mathrm{AMH}$ was the most promising predictive markers for ovarian aging, and timing of menopause [16].

Unlike other reproductive hormones, AMH is detectable in females of all ages. Circulating AMH levels show only minor fluctuations during childhood and adolescence [17]. The negative AMH-FSH correlation in prepubertal girls supports the notion that $\mathrm{AMH}$ is a quantitative marker of ovarian follicles even in young girls [17]. In adults, AMH levels peak in the early twenties [18], but begin to decline after that [19], and are virtually undetectable during menopause [19]. However, the timing of menopause appears to vary according to the ethnic/racial background, exemplified by the early onset of menopause in Africans and delayed onset of menopause in Asians [20]. Few multi-ethnic studies confirmed decline in AMH as determinant of menopause [21, 22], suggesting race/ ethnic contribution to differences in ovarian reserve and timing of menopause, and variation in risk for post menopause-associated disease [21].

Given the progressive rise in the need for in vitro fertilization (IVF) in Lebanon, which often requires multiple ovarian stimulation/embryo transfer cycles due to many factors, including age, type of infertility treatment, and $\mathrm{AMH}$ basal levels [23], we investigated the agedependent changes in circulating AMH levels in a large group of healthy Lebanese women. In addition, we report on the contribution of altered AMH levels on FSH and $\mathrm{LH}$ values.

\section{Methods \\ Study subjects}

The cross-sectional study was performed at St. Marc Medical Center, an integrated clinical diagnostics center located in East Beirut. Between 2010 and 2015, 1190 healthy volunteer women, age 17-54 years, were recruited, after obtaining information on age and area of residence. Inclusion criteria were regular menses (duration of cycle: 25 35 days, with 5 days or less inter-cycle difference), and presence of both ovaries. Exclusion criteria included current or hormone therapy in the past 6 months, history of confirmed infertility, PCOS, overt autoimmune disease, along with chronic, metabolic, and endocrine disease (including hyperandrogenism). After disclosing information about study subjects' reproductive history and regularity of their menstrual cycle, written informed consent were obtained from them followed by peripheral venous blood samples for AMH, FSH and LH levels assessment. All blood samples were collected on day 3 of the same menstrual cycle. St. Marc Medical Center Research and Ethics Committee (SMMC-RE02-01/09; granted on 7 March 2009) approved the study protocol, which was done according to Helsinki II guidelines.

\section{AMH assay}

Blood samples for AMH determination were collected in plain tubes, allowed to clot for 15-20 min, and were centrifuged at $4000 \mathrm{rpm}$ for $10 \mathrm{~min}$, and serum aliquots were stored at $-20^{\circ} \mathrm{C}$; freeze-thawing was avoided. Serum $\mathrm{AMH}$ was measured by AMH Gen II ELISA kit (Beckman Coulter, Brea, CA). AMH concentrations were expressed in $\mathrm{ng} / \mathrm{ml}$ (conversion factor: $1 \mathrm{ng} / \mathrm{ml}=7.14 \mathrm{pM}$ ). The assay detection limit was $0.14 \mathrm{ng} / \mathrm{ml}$; intra- and inter-assay coefficients of variation were $5-9 \%$ and $7-12 \%$, respectively. Samples which were below the limit of detection of AMH $(<2 \mathrm{pg} / \mathrm{mL})$, were excluded to avoid using null values. FSH $(\mathrm{mIU} / \mathrm{ml})$ and $\mathrm{LH}(\mathrm{mIU} / \mathrm{ml})$ were quantitated using Cobas e411 (Roche Diagnostics, Indianapolis, IN).

\section{Statistical analysis}

$\mathrm{AMH}$ levels were presented as mean $\pm \mathrm{SD}$, and the 5 th, 25th, 50th, 75th, and 95th percentiles were determined with SPSS v. 23 (IBM, Armonk, NY). Study subjects were stratified into eight age categories: $17-20$ years, $20-25$ years, $>25-30$ years, $>30-35$ years, $>35-40$ years, $>40-45$ years, $>45-50$ years, and $51-61$ years. Differences between age, AMH, FSH, LH, and LH/FSH ratio between the eight groups were determined by ANOVA; $P<0.05$ considered statistically significant. Multivariate hierarchical linear regression modeling was performed 
to assess the independent effect of AMH on LH, FSH, and LH/FSH ratio, after adjusting for age as the independent variable. Beta coefficients (SE) and 95\% confidence intervals $(\mathrm{CI})$, as well as $P$ values were reported for these models.

\section{Results}

\section{Age-dependent decline in AMH levels}

Table 1 summarizes the mean and median AMH values among 1190 female participants, who were grouped into eight age groups. At blood sampling, there were 27 women younger than 20 years, and 13 women older than 50 years of age at blood sampling; most $(879 ; 73.9 \%)$ were in the $30-45$ year age categories. The mean $( \pm \mathrm{SD})$ and median AMH values recorded for unselected study participants were $2.47 \pm 2.29$ and 1.80 , respectively. There was an inverse proportion of AMH and subject's age $(P<0.001)$, which declined from $5.14 \pm 3.21 \mathrm{ng} / \mathrm{ml}$ in the $20-25$ year age group, to $0.68 \pm 0.45 \mathrm{ng} / \mathrm{ml}$ in women older than 50 years (Table 1 ). The average yearly decrease in median AMH levels was $0.27 \mathrm{ng} / \mathrm{ml} /$ year through age 35 , but then diminished to $0.12 \mathrm{ng} / \mathrm{ml} /$ year after age 35 (Table 1). AMH 5th, 25th, 50th, 75th, and 95th percentile analysis confirmed the age-decline in AMH levels (Table 1). Receiver operating characteristic (ROC) curve analysis demonstrated high sensitivity and specificity of age as determinant of AMH levels, and Spearman correlation coefficient value obtained was -0.339 , and largest area under the curve $(0.857 \pm 0.038 ; 95 \% \mathrm{CI}=95.6-100)$ was obtained (Fig. 1).

\section{Age-dependent changes in $\mathrm{FSH}$ and $\mathrm{LH}$ relative to $\mathrm{AMH}$} In contrast to $\mathrm{AMH}$, FSH follow the opposite direction. FSH values progressively increased from [median (range)] $5.89(0.11-62.10) \mathrm{ng} / \mathrm{ml}$ in the $20-25$-year category females to $9.17(0.18-167.00) \mathrm{ng} / \mathrm{ml}$ in $40-45$ year-old women, and further after the age 50 years. No clear trend for age-related changes in LH levels were seen $(P=0.299)$. On the other hand, age-dependent

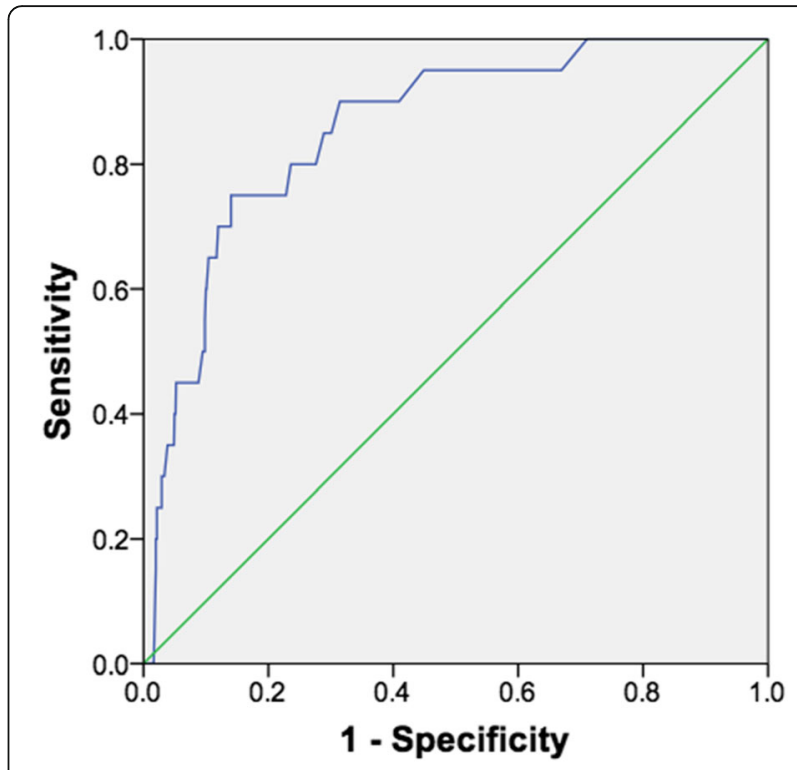

Fig. 1 ROC curve of serum levels of AMH changes according to age. The Spearman's correlation coefficient between AMH and age was $-0.339(P<0.0001)$, and the area under ROC curves of AMH was $0.857 \pm 0.038$ (asymptomatic $95 \% \mathrm{Cl}=0.783-0.932$ )

changes in LH/FSH ratio paralleled those of AMH; they dropped from $1.16(0.11-7.59)$ in $20-25$ year-old females to $0.56(0.27-2.78)$ in $45-50$ year-old females (Table 2).

\section{Correlation between AMH and LH/FSH levels}

Multivariate hierarchical linear regression modeling was developed to assess the independent effect of AMH on FSH and LH, adjusted for age. Beta coefficients (SE) and $P$ values were reported for these models. Results from Table 3 indicated that $\mathrm{AMH}$ was a significant predictor of FSH $(P=0.029)$, but not LH $(P=0.568)$, along with LH/FSH ratio $(P<0.001)$. This persisted after controlling for age, which did not contribute significantly to baseline $\mathrm{LH}$ and FSH prediction.

Table 1 Age-specific AMH levels for 1190 Lebanese women at defined age intervals

\begin{tabular}{|c|c|c|c|c|c|c|c|c|c|}
\hline \multicolumn{10}{|c|}{ AMH Perecntiles ' } \\
\hline Age groups & Number & Menopausal & Median & Mean \pm SD & 5th & 25th & 50th & 75th & 95th \\
\hline$\overline{\mathrm{ALL}}$ & 1190 & $36(3.0)^{2}$ & 1.80 & $2.47 \pm 2.29$ & 0.45 & 0.85 & 1.80 & 3.10 & 7.44 \\
\hline $17-20$ years & 27 & $0(0.0)$ & 7.25 & $6.71 \pm 2.91$ & 1.40 & 4.40 & 7.25 & 9.50 & 10.80 \\
\hline $20-25$ years & 55 & $0(0.0)$ & 4.47 & $5.14 \pm 3.21$ & 0.93 & 2.80 & 4.47 & 7.00 & 12.04 \\
\hline$>25-30$ years & 111 & $0(0.0)$ & 3.60 & $4.54 \pm 2.90$ & 1.00 & 2.40 & 3.60 & 6.50 & 11.00 \\
\hline$>30-35$ years & 219 & $0(0.0)$ & 2.55 & $3.19 \pm 2.11$ & 0.95 & 1.95 & 2.55 & 3.95 & 7.20 \\
\hline$>35-40$ years & 306 & $0(0.0)$ & 1.80 & $2.23 \pm 1.75$ & 0.51 & 1.00 & 1.80 & 2.80 & 6.05 \\
\hline$>40-45$ years & 354 & $5(1.4)$ & 1.00 & $1.37 \pm 1.01$ & 0.42 & 0.70 & 1.00 & 1.75 & 3.61 \\
\hline$>45-50$ years & 105 & $19(18.1)$ & 0.70 & $0.89 \pm 0.63$ & 0.27 & 0.50 & 0.70 & 1.00 & 2.38 \\
\hline $51-61$ years & 13 & $12(92.3)$ & 0.60 & $0.68 \pm 0.45$ & 0.20 & 0.43 & 0.60 & 0.70 & 0.94 \\
\hline
\end{tabular}

${ }^{1} P<0.001$ among different groups

${ }^{2}$ Number of subjects (percent total within group) 
Table 2 Comparison of age, AMH, LH, FSH and LH/FSH ratio in different age groups

\begin{tabular}{lllllll}
\hline Age groups & $\mathrm{N}$ & Age & AMH $(\mathrm{ng} / \mathrm{ml})$ & FSH & LH & LH/FSH ratio \\
\hline ALL & 1191 & $37.63 \pm 7.20$ & $2.47 \pm 2.29$ & $7.96(0.09-177.80)$ & $7.02(0.10-113.60)$ & $0.72(0.02-7.59)$ \\
17-20 years & 27 & $19.04 \pm 2.17$ & $6.71 \pm 2.91$ & $5.56(4.46-60.61)$ & $13.62(2.08-68.42)$ & $1.63(0.47-5.08)$ \\
20-25 years & 55 & $23.46 \pm 1.27$ & $5.14 \pm 3.21$ & $5.89(0.11-62.10)$ & $7.43(0.10-35.82)$ & $1.16(0.11-7.59)$ \\
$>$ 25-30 years & 111 & $28.20 \pm 1.47$ & $4.54 \pm 2.90$ & $6.06(0.78-23.91)$ & $6.51(0.10-13.71)$ & $1.03(0.13-2.13)$ \\
$>30-35$ years & 219 & $33.15 \pm 1.39$ & $3.19 \pm 2.11$ & $7.44(3.29-177.80)$ & $6.42(1.48-84.80)$ & $0.78(0.19-4.47)$ \\
$>35-40$ years & 306 & $38.28 \pm 1.44$ & $2.23 \pm 1.75$ & $7.38(0.09-160.30)$ & $7.22(0.10-75.71)$ & $0.77(0.02-3.84)$ \\
$>40-45$ years & 355 & $43.01 \pm 1.43$ & $1.37 \pm 1.01$ & $9.17(0.18-167.00)$ & $6.84(0.10-113.60)$ & $0.64(0.18-4.00)$ \\
$>45-50$ years & 105 & $47.35 \pm 1.35$ & $0.89 \pm 0.63$ & $11.31(2.30-108.40)$ & $7.77(3.39-50.72)$ & $0.56(0.27-2.78)$ \\
$51-61$ years & 13 & $53.15 \pm 2.79$ & $0.68 \pm 0.45$ & $38.43(3.99-88.30)$ & $24.10(2.07-51.93)$ & $0.58(0.18-0.75)$ \\
$P$ & & & $<0.001$ & $1.09 \times 10^{-7}$ & 0.942 & $4.42 \times 10^{-4}$ \\
Chi square & & & 86.88 & 45.51 & 2.29 & 26.32 \\
\hline
\end{tabular}

\section{Discussion}

This study was prompted by the need for reliable marker of diminishing ovarian function, apart from FSH and estradiol $[18 ; 24]$, and independent of the phases of the menstrual cycle $[10,19]$. In view of its utility in evaluating fertility (ovarian reserve), assessment of age-specific variation in $\mathrm{AMH}$ levels is central for infertility workup $[9,12]$, as serum $\mathrm{AMH}$ reflects $\mathrm{AMH}$ production only from functioning follicles [24]. This is the first study that addresses age-specific serum AMH levels in 1190 Arabic-speaking Lebanese women, and spans the reproductive lifespan from 17 to 54 years.

The inverse relationship between serum AMH and age was previously reported for several ethnic groups, and our findings on Lebanese women confirm this negative association. The kinetics of $\mathrm{AMH}$ decline was paralleled with a similar decline in LH/FSH ratio, both of which were inversely related to FSH or $\mathrm{LH}$ levels but was attenuated for FSH was when validated by regression analysis. Insofar as the timing of natural menopause, and age-dependent reduction in $\mathrm{AMH}$ vary according to race and ethnicity $[20,21]$, this study identifies populationbased reference range for $\mathrm{AMH}$ concentration and yearly decline levels in Lebanese women.

In agreement with earlier findings, marked heterogeneity in $\mathrm{AMH}$ values were seen among our cohort of Arabic-speaking Lebanese women, especially among younger compared with older women, suggesting a role in follicular development $[19,25,26]$. The impact of age on decline of AMH levels was analyzed at two levels, as continuous and later categorical (5-year age groups), and confirmed by ROC analysis (area under ROC curve = 0.857). This was in agreement with earlier studies demonstrating that ageing is linked with altered $\mathrm{AMH}$ expression, irrespective of follicular cohort [9], and that patients with advancing age (hence low follicular count) had drastically low levels of AMH when compared to patients with a higher follicular count [10, 26]. The AMH percentiles (5th, 25th, 50th, 75th and 95th) obtained in our study was reminiscent of the age-related normograms (5th, 25th, 50th, 75th, and 95th AMH percentiles) reported earlier [27].

AMH and FSH are highly correlated [19], and agespecific fluctuations in their values was previously demonstrated [25]. While the mean (and median) FSH and LH established for Lebanese women are consistent with those reported for healthy women in other ethnic groups, the wide variation in FSH $(n=30)$ and $\mathrm{LH}(n=10)$ suggest the presence of an unidentified conditions. The selection of the study subjects relied on self-reported health condition, and thus the abnormally high values of FSH and $\mathrm{LH}$ seen in 30 and 10 participants, respectively, can be explained by undiagnosed or asymptomatic condition (including PCOS) [28], contribution of modifying factors (especially smoking) [29], status (and days) of the menstrual cycle, and varied assay conditions.

On the other hand, AMH determination at any day of a normal menstrual cycle was shown to be predictive of baseline FSH and LH levels [3, 10, 11]. Similar to AMH, $\mathrm{FSH} / \mathrm{LH}$ ratio reflects ovarian reserve and is used as a

Table 3 Regression analysis of AMH levels as predictors of LH and FSH levels

\begin{tabular}{|c|c|c|c|c|c|c|}
\hline & \multicolumn{3}{|l|}{ Unadjusted } & \multicolumn{3}{|l|}{ Age-Adjusted } \\
\hline & $P$ & $\beta(S D)$ & $95 \% \mathrm{Cl}$ & $P$ & $\beta(S D)$ & $95 \% \mathrm{Cl}$ \\
\hline$\overline{\mathrm{LH}}$ & 0.065 & $-0.042(0.023)$ & $-0.086-0.003$ & 0.568 & $0.006(0.010)$ & $-0.014-0.025$ \\
\hline FSH & 0.729 & $-0.005(0.014)$ & $-0.032-0.032$ & 0.029 & $-0.035(0.016)$ & $-0.066--0.004$ \\
\hline $\mathrm{LH} / \mathrm{FSH}$ & $1.95 \times 10^{-8}$ & $1.369(0.238)$ & $0.901-1.837$ & $7.62 \times 10^{-10}$ & $1.081(0.170)$ & $0.746-1.416$ \\
\hline
\end{tabular}


laboratory predictor of diminished ovarian reserve and forecaster of response to controlled ovarian stimulation [30]. The benefit of the FSH/LH ratio is that it uses already standardized and universally obtained day 3 laboratory values [30]. This was also shown for normoovulatory [13], but not women with PCOS [31].

AMH determination was proposed as predictor of menopause $[2,16,32]$, and very low, even undetectable, $\mathrm{AMH}$ levels are commonly seen five years prior to menopause. By comparison, the predictive value of FSH levels as determinant of aging predictor is lower than that of AMH, since AMH levels decline earlier than FSH $[16,32]$. Our findings are consistent with the physiologic changes associated with aging in females [5]. Our results showed AMH levels were high predictors of LH/FSH ratio, more so than FSH levels, while LH levels did not correlate with AMH levels. Mixed association of FSH and AMH levels were reported $[13,26]$, which are likely attributed to ethnic variation [20-22], and presence of comorbidities [24, 27, 31, 33]. A significant negative correlation was found between LH/FSH ratio and age, which paralleled that of $\mathrm{AMH}$, in agreement with a recent study [13]. This suggests that LH/FSH ratio is surrogate for AMH level in situations and centers where AMH measurement may not be feasible, as suggested [13].

\section{Conclusions}

In conclusion, our study confirms the age-specific changes in AMH levels, along with LH/FSH ratio, which in turn translates into a reliable way of determining ovarian reserve, more so than FSH or LH. This does not indicate a direct feedback mechanism between AMH and LH or FSH. Instead, we favor the notion that they are independent indicators of ovarian reserve. Strengths of this study include the availability of AMH data of females aged 1754 years, thus allowing modeling of age dependent $\mathrm{AMH}$ profile. In addition, the concurrent measurement of LH and FSH with AMH are best suited to study the association between $\mathrm{AMH}$ and both hormones and their ratio, and that given the profile of participating women, results obtained are likely representative of general female population. Our study had some shortcomings as well. Our study comprised only healthy females, thus questioning the generalizability of the findings on women with infertility and metabolic abnormalities, including PCOS $[15,24$, $31]$ and infertility $[12,14,19]$, and vitamin D deficiency [34]. Furthermore, our study involved Lebanese women, thus necessitating parallel investigations on women from related and distant ethnic backgrounds. Despite these shortcomings, our results confirm the superiority of AMH determination in the follow up of ovarian reserve, given the stability of AMH throughout the cycle and ease of sampling during the day.

\section{Abbreviations}

AMH: Anti-Müllerian hormone; Cl: Confidence intervals; FSH: Folliclestimulating hormone; GnRH: Gonadotropin-releasing hormone; IVF: in vitro fertilization; LH: Luteinizing hormone; PCOS: Polycystic ovary syndrome; ROC: Receiver operating characteristic; SD: Standard deviation; SE: Standard error

\section{Acknowledgements}

Not applicable.

\section{Authors' contributions}

All authors have read and approved the manuscript: ER was responsible for the main investigation and methodology used; GA for writing - original draft; RRF for resources and data curation, while WAY for formal analysis; writing - review and editing, and supervision.

\section{Funding}

This research did not receive any specific grant from funding agencies in the public, commercial, or not-for-profit sectors.

\section{Availability of data and materials}

The datasets used and/or analyzed during the current study are available from the corresponding author on reasonable request.

\section{Ethics approval and consent to participate}

St. Marc Medical Center Research and Ethics Committee (SMMC-RE02-01/09; granted on 7 March 2009) approved the study protocol, and all participating subjects agreed to voluntarily participate in the study by signing a consent form.

\section{Consent for publication}

Not applicable.

\section{Competing interests}

The authors declare that they have no competing interests.

\section{Author details}

${ }^{1}$ St. Marc Medical and Diagnostic Center, Ashrafieh, Beirut, Lebanon. ${ }^{2}$ School of Medicine, Nazarbayev University, Nur-Sultan, Astana, Kazakhstan.

${ }^{3}$ Department of Obstetrics and Gynecology, Hôtel-Dieu de France, Beirut, Lebanon. ${ }^{4}$ Faculte' des Sciences de Tunis, Universite' de Tunis El Manar,

Tunis, Tunisia. ${ }^{5}$ College of Health Sciences, Abu Dhabi University, Abu Dhabi, United Arab Emirates.

Received: 16 July 2019 Accepted: 18 June 2020

Published online: 26 June 2020

\section{References}

1. Cate RL, Mattaliano RJ, Hession C, Tizard R, Farber NM, Cheung A, et al. Isolation of the bovine and human genes for Müllerian inhibiting substance and expression of the human gene in animal cells. Cell. 1986;45:685-98.

2. Josso N. WOMEN IN REPRODUCTIVE SCIENCE: Anti-Müllerian hormone: a look back and ahead. Reproduction. 2019;158:F81-9.

3. Rey R, Lukas-Croisier C, Lasala C, Bedecarrás P. AMH/MIS: what we know already about the gene, the protein and its regulation. Mol Cell Endocrinol. 2003;211:21-31.

4. Kuiri-Hänninen T, Kallio S, Seuri R, Tyrväinen E, Liakka A, Tapanainen J. Postnatal developmental changes in the pituitary-ovarian axis in preterm and term infant girls. J Clin Endocrinol Metab. 2011;96:3432-9.

5. Josso N, di Clemente N, Gouédard L. Anti-Müllerian hormone and its receptors. Mol Cell Endocrinol. 2001;179(1-2):25-32.

6. Mullen RD, Wang Y, Liu B, Moore EL, Behringer RR. Osterix functions downstream of anti-Müllerian hormone signaling to regulate Müllerian duct regression. Proc Natl Acad Sci U S A. 2018;115:8382-7.

7. Shin SY, Lee JR, Noh GW, Kim HJ, Kang WJ, Kim SH, Chung JK. Analysis of serum levels of anti-Müllerian hormone, Inhibin B, insulin-like growth factorI, insulin-like growth factor binding Protein-3, and follicle-stimulating hormone with respect to age and menopausal status. J Korean Med Sci. 2008;23:104-10. 
8. Lenton EA, Sexton L, Lee S, Cooke ID. Progressive changes in LH and FSH and LH: FSH ratio in women throughout reproductive life. Maturitas. 1988; 10(1):35-43.

9. Visser JA, de Jong FH, Laven JS, Themmen AP. Anti-Müllerian hormone: a new marker for ovarian function. Reproduction. 2006;131:1-9.

10. Hehenkamp WJ, Looman CW, Themmen AP, de Jong FH, Te Velde ER, Broekmans FJ. Anti-Müllerian hormone levels in the spontaneous menstrual cycle do not show substantial fluctuation. J Clin Endocrinol Metab. 2006;91:4057-63.

11. Streuli I, Fraisse T, Pillet C, Ibecheole V, Bischof P, de Ziegler D. Serum antiMüllerian hormone levels remain stable throughout the menstrual cycle and after oral or vaginal administration of synthetic sex steroids. Fertil Steril. 2008;90:395-400.

12. Nardo LG, Gelbaya TA, Wilkinson H, Roberts SA, Yates A, Pemberton $P$, et al. Circulating basal anti-Müllerian hormone levels as predictor of ovarian response in women undergoing ovarian stimulation for in vitro fertilization. Fertil Steril. 2009;92:1586-93.

13. Lee JE, Yoon SH, Kim HO, Min EG. Correlation between the serum luteinizing hormone to follicle stimulating hormone ratio and the antiMüllerian hormone levels in normo-ovulatory women. J Korean Med Sci. 2015;30:296-300.

14. Hazout A, Bouchard $P$, Seifer DB, Aussage $P$, Junca AM, Cohen-Bacrie $P$. Serum antimüllerian hormone/müllerian-inhibiting substance appears to be a more discriminatory marker of assisted reproductive technology outcome than follicle-stimulating hormone, inhibin B, or estradiol. Fertil Steril. 2004; 82:1323-9.

15. Yetim A, Yetim Ç, Baş F, Erol OB, Çığ G, Uçar A, et al. Anti-Müllerian hormone and inhibin-a, but not inhibin-B or insulin-like peptide-3, may be used as surrogates in the diagnosis of polycystic ovary syndrome in adolescents: preliminary results. J Clin Res Pediatr Endocrinol. 2016;8:288-97.

16. Depmann M, Eijkemans MJ, Broer SL, Scheffer GJ, van Rooij IA, Laven JS, et al. Does anti-Müllerian hormone predict menopause in the general population? Results of a prospective ongoing cohort study. Hum Reprod. 2016;31:1579-87.

17. Hagen CP, Aksglaede L, Sørensen K, Mouritsen A, Andersson AM, Petersen $J H$, Main KM, Juul A. Individual serum levels of anti-Müllerian hormone in healthy girls persist through childhood and adolescence: a longitudinal cohort study. Hum Reprod. 2012;27:861-6.

18. Racine C, Rey R, Forest MG, Louis F, Ferré A, Huhtaniemi I, Josso N, di Clemente N. Receptors for anti-Müllerian hormone on Leydig cells are responsible for its effects on steroidogenesis and cell differentiation. Proc Natl Acad Sci U S A. 1998;95:594-9.

19. van Rooij IA, Broekmans FJ, Scheffer GJ, Looman CW, Habbema JD, de Jong $\mathrm{FH}$, et al. Serum antimullerian hormone levels best reflect the reproductive decline with age in normal women with proven fertility: a longitudinal study. Fertil Steril. 2005;83:979-87.

20. Bleil ME, Gregorich SE, Adler NE, Sternfeld B, Rosen MP, Cedars MI. Race/ ethnic disparities in reproductive age: an examination of ovarian reserve estimates across four race/ethnic groups of healthy, regularly cycling women. Fertil Steril. 2014;101:199-207.

21. Henderson KD, Bernstein L, Henderson B, Kolonel L, Pike MC. Predictors of the timing of natural menopause in the multiethnic cohort study. Am J Epidemiol. 2008;167:1287-94.

22. Seifer DB, Golub ET, Lambert-Messerlian G, Benning L, Anastos K, Watts DH, et al. Variations in serum müllerian inhibiting substance between white, black, and Hispanic women. Fertil Steril. 2009;92:1674-8.

23. Khalife D, Nassar A, Khalil A, Awwad J, Abu Musa A, Hannoun A, El Taha L, Khalifeh F, Abiad M, Ghazeeri G. Cumulative live-birth rates by maternal age after one or multiple in vitro fertilization cycles: an institutional experience. Int J Fertil Steril. 2020;14:34-40.

24. Lebkowska A, Adamska A, Karczewska-Kupczewska M, Nikołajuk A, Otziomek E, Milewski M, et al. Serum anti-Müllerian hormone concentration in women with polycystic ovary syndrome and type 1 diabetes mellitus. Metabolism. 2016;65:804-11.

25. Barad DH, Weghofer A, Gleicher N. Comparing anti-Mullerian hormone $(\mathrm{AMH})$ and follicle- stimulating hormone (FSH) as predictors of ovarian function. Fertil Steril. 2009;91:1553-5.

26. Jamil Z, Fatima SS, Cheema Z, Baig S, Choudhary RA. Assessment of ovarian reserve: anti-Mullerian hormone versus follicle stimulating hormone. J Res Med Sci. 2016;21:100.

27. La Marca A, Papaleo E, Grisendi V, Argento C, Giulini S, Volpe A. Development of a nomogram based on markers of ovarian reserve for the individualisation of the follicle-stimulating hormone starting dose in in vitro fertilisation cycles. BJOG. 2012;119:1171-9.

28. Malini NA, Roy GK. Evaluation of different ranges of LH:FSH ratios in polycystic ovarian syndrome (PCOS) - clinical based case control study. Gen Comp Endocrinol. 2018;260:51-7.

29. Whitcomb BW, Bodach SD, Mumford SL, Perkins NJ, Trevisan M, WactawskiWende J, et al. Ovarian function and cigarette smoking. Paediatr Perinat Epidemiol. 2010;24:433-40.

30. Kofinas JD, Elias RT. Follicle-stimulating hormone/luteinizing hormone ratio as an independent predictor of response to controlled ovarian stimulation. Womens Health. 2014;10:505-9.

31. Chun S. Serum luteinizing hormone level and luteinizing hormone/folliclestimulating hormone ratio but not serum anti-Müllerian hormone level is related to ovarian volume in Korean women with polycystic ovary syndrome. Clin Exp Reprod Med. 2014;41:86-91.

32. Kruszyńska A, Słowińska-Srzednicka J. Anti-Müllerian hormone (AMH) as a good predictor of time of menopause. Prz Menopauzalny. 2017;2:47-50.

33. Magri F, Schena L, Capelli V, Gaiti M, Zerbini F, Brambilla E, et al. AntiMullerian hormone as a predictor of ovarian reserve in ART protocols: the hidden role of thyroid autoimmunity. Reprod Biol Endocrinol. 2015;13:106.

34. Drakopoulos P, van de Vijver A, Schutyser V, Milatovic S, Anckaert E, Schiettecatte J, et al. The effect of serum vitamin D levels on ovarian reserve markers: a prospective cross-sectional study. Hum Reprod. 2017;32:208-14

\section{Publisher's Note}

Springer Nature remains neutral with regard to jurisdictional claims in published maps and institutional affiliations.
Ready to submit your research? Choose BMC and benefit from:

- fast, convenient online submission

- thorough peer review by experienced researchers in your field

- rapid publication on acceptance

- support for research data, including large and complex data types

- gold Open Access which fosters wider collaboration and increased citations

- maximum visibility for your research: over $100 \mathrm{M}$ website views per year

At $\mathrm{BMC}$, research is always in progress.

Learn more biomedcentral.com/submissions 